\title{
Correction to: Cardiac Contractility Modulation: an Important Therapy in the Treatment of Advanced Heart Failure
}

\author{
Jonathan B. Edelson ${ }^{1} \cdot$ Michael V. Genuardi ${ }^{2} \cdot$ Pasquale Santangeli $^{2} \cdot$ Edo Y. Birati $^{2}$
}

Published online: 8 September 2020

(C) Springer Science+Business Media, LLC, part of Springer Nature 2020

Correction to: Current Cardiology Reports (2020) 22: 81 https://doi.org/10.1007/s11886-020-01330-0

The article title in the original publication contains a mistake.

The correct title is presented in this erratum.

Publisher's Note Springer Nature remains neutral with regard to jurisdictional claims in published maps and institutional affiliations.

The online version of the original article can be found at https://oi.org/ 10.1007/s11886-020-01330-0

Jonathan B. Edelson

Edelsonj@email.chop.edu

Michael V. Genuardi

Michael.Genuardi@pennmedicine.upenn.edu

Pasquale Santangeli

Pasquale.Santangeli@pennmedicine.upenn.edu

Edo Y. Birati

Edo.Birati@pennmedicine.upenn.edu

1 Division of Cardiology, Cardiac Center, the Children's Hospital of Philadelphia, Perelman School of Medicine, University of

Pennsylvania, Philadelphia, PA, USA

2 Cardiovascular Division, Department of Medicine, Perelman School of Medicine, University of Pennsylvania, Philadelphia, PA, USA 